\title{
Evidence from "Köppen signatures" of fossil plant assemblages for effective heat transport of Gulf Stream to subarctic North Atlantic during Miocene cooling
}

\author{
T. Denk ${ }^{1}$, G. W. Grimm ${ }^{1}$, F. Grímsson ${ }^{2}$, and R. Zetter ${ }^{2}$ \\ ${ }^{1}$ Swedish Museum of Natural History, Department of Palaeobiology, Box 50007, 10405 Stockholm, Sweden \\ ${ }^{2}$ University of Vienna, Department of Palaeontology, Althanstrasse 14, 1090 Vienna, Austria \\ Correspondence to: T. Denk (thomas.denk@nrm.se)
}

Received: 8 July 2013 - Published in Biogeosciences Discuss.: 15 August 2013

Revised: 29 October 2013 - Accepted: 2 November 2013 - Published: 6 December 2013

\begin{abstract}
Shallowing of the Panama Sill and the closure of the Central American Seaway initiated the modern Loop Current-Gulf Stream circulation pattern during the Miocene, but no direct evidence has yet been provided for effective heat transport to the northern North Atlantic during that time. Climatic signals from 11 precisely dated plantbearing sedimentary rock formations in Iceland, spanning 15-0.8 million years (Myr), resolve the impacts of the developing Miocene global thermohaline circulation on terrestrial vegetation in the subarctic North Atlantic region. "Köppen signatures" were implemented to express climatic properties of fossil plant taxa and their potential modern analogues using the principal concept of the generic Köppen-Geiger climate system, which is based on plant distribution patterns. Using Köppen signatures and the correlation between Köppen climate zones and major global vegetation zones, fossil assemblages were used to trace major vegetation shifts. This evidence was combined with evidence from tectonics and palaeoceanography. In contrast to the global climatic trend, the vegetation record reveals no cooling between $\sim 15$ and $12 \mathrm{Myr}$, whereas periods of climatic deterioration between 12 and $10 \mathrm{Myr}, 8$ and $4 \mathrm{Myr}$, and in the Pleistocene are in phase with increased pulses of ice-rafted debris in the Northern Hemisphere. The observed sequence of climate change in the northern North Atlantic can most likely be explained by an effective Gulf Stream-mediated heat transport from the middle Miocene onwards.
\end{abstract}

\section{Introduction}

The Mid-Miocene Climatic Optimum (MMCO) at 17-15 million years (Myr) was the last phase of markedly warm climate in the Cenozoic (Zachos et al., 2001). The MMCO was followed by the Mid-Miocene Climate Transition (MMCT) at 14.2-13.8 Myr correlated with the growth of the East Antarctic Ice Sheet (Shevenell et al., 2004). In the Northern Hemisphere this cooling is reflected by continuous sea ice in the central Arctic Ocean since 12 Myr (Frank et al., 2008). Further south, the exposed northern Barents Sea shelf was already glaciated by $\sim 15-14 \mathrm{Myr}$ and was the main source of glacial detritus to the Fram Strait area (Knies and Gaina, 2008), where the first pulses of ice- rafted debris (IRD) are recorded at $\sim 14 \mathrm{Myr}$ (Wolf-Welling et al., 1996) and at $\sim 12.6 \mathrm{Myr}$ in the Norwegian Sea (Wolf-Welling et al., 1996; Thiede et al., 1998). The dramatic change in Earth's climate from the MMCO to the MMCT is well documented in marine and terrestrial sedimentary records from both hemispheres. Abrupt cooling after the MMCO recognized globally in marine isotope records (Zachos et al., 2001; Shevenell et al., 2004; Knies and Gaina, 2008) is also documented in the palaeobotanical records of Antarctica (Lewis et al., 2008) and Alaska (Wolfe, 1994; White et al., 1997). This change was accompanied by major oceanographic reorganizations. The timing of the MMCO coincided with the opening of the North Atlantic-Arctic gateway (Jakobsson et al., 2007) that permitted water and ice exchange between the Arctic and Atlantic oceans and established a steeper oceanic thermal gradient. Contemporaneously, global deep-sea unconformities indicate that circumequatorial circulation via 
the Central American Seaway was disrupted $\sim 16-15 \mathrm{Myr}$ (Keller and Barron, 1983), and seismic stratigraphic investigations in the eastern Gulf of Mexico also suggest a major change in ocean circulation (Keller and Barron, 1983; Mullins et al., 1987; Duque-Caro, 1990; Flower and Kennett, 1995; Nisancioglu et al., 2003). Due to the rise of the Panama Sill (Mullins et al., 1987) and closure of the Central American Seaway (Montes et al., 2012), the Equatorial Current and weak proto-Gulf Stream of the early Miocene were replaced by the more intense Caribbean Loop CurrentGulf Stream system between 15 and $12 \mathrm{Myr}$ (Mullins et al., 1987). The northward deflection of deep currents and the initiation of modern Loop Current-Gulf Stream patterns in conjunction with an open North Atlantic-Arctic gateway likely intensified the pre-existing weak thermohaline circulation in the Nordic Seas (Knies and Gaina, 2008) and might have led to surface-temperature deviations in the subarctic North Atlantic that were similar to today (Kaspi and Schneider, 2011). Direct observations of the effect of Gulf Stream-mediated heat transport to the subarctic North Atlantic during the Neogene have long been hindered by the apparent lack of a continuous terrestrial sedimentary record in the northern North Atlantic, Norwegian Sea, and Greenland Sea areas.

Here, we use an extensive palaeobotanical record from Neogene and Quaternary sediments in Iceland spanning 15 to $0.8 \mathrm{Myr}$ (Denk et al., 2011) to evaluate climate development in this region and to compare this to global climate patterns (Zachos et al., 2001). We used Köppen climate types (Köppen, 1936; Kottek et al., 2006; Peel et al., 2007) and major vegetation zones (Walter, 1973; Schroeder, 1998) covered by the geographical and altitudinal distribution ranges of potential modern analogues (PMA) of the fossil plant taxa to infer climate shifts for the late Cenozoic of Iceland.

\section{Material}

In a recent monographic work (Denk et al., 2011) on late Cenozoic plant fossils of Iceland, 342 taxa based upon macro- and microfossils were described, and their systematic affinities determined (Table A1). The material investigated originates from 11 plant-bearing sedimentary formations exposed at 46 localities (Table 1) and combines material from historical collections stored in the Swedish Museum of Natural History, Stockholm, the Icelandic Institute (Museum) of Natural History, Reykjavík, and the Geological Museum, Copenhagen, with material collected during several new field campaigns (1998-2010).

The age of the sedimentary formations (Table 1), and hence of the fossil assemblages, is well constrained due to their position between basalts (Denk et al., 2011). Absolute ages are available for most bracketing basalts, for the remainder ages have been constrained by means of palaeomagnetic correlation (McDougall et al., 1984; Hardarson et al., 1997; Kristjansson et al., 2003). The oldest sedimentary forma- tion exposed in Iceland, the Selárdalur-Botn Formation, is of early middle Miocene age ( $\sim 15 \mathrm{Myr})$; the youngest sedimentary formation covered by the monograph is of late Pleistocene age ( $\sim 800 \mathrm{kyr}$; Denk et al., 2011$)$. Iceland is the only known terrestrial place in the subarctic North Atlantic providing a relatively continuous sedimentary and plant fossil record for the past 15 million years.

\section{Methods}

The present paper is introducing a new method to infer climate evolution from plant fossil proxies. The method and its background are explained in detail in the following.

\subsection{The Köppen-Geiger climate classification}

The climate classification by Wladimir Köppen (Köppen, 1884, 1936; Kottek et al., 2006; Peel et al., 2007) is currently the most widely used. It is a generic classification that is based chiefly on two complex criteria: the degree and seasonal distribution of precipitation and of warmth (Barry and Chorley, 2003). The main climate types except for the arid ("dry") climates (Köppen climate type B) are based on monthly mean temperatures (Table 2). The temperature limits in Köppen's classification were originally chosen based on several observations: the $10^{\circ} \mathrm{C}$ summer isotherm roughly correlates with the poleward limit of tree growth defining the southern (on the Northern Hemisphere) or northern limit (Southern Hemisphere) of the polar (Arctic and Antarctic) climates ("ice climates", Köppen climate type E). The $18^{\circ} \mathrm{C}$ winter isotherm provides a threshold for a broad range of tropical plants and defines the boundary of the "equatorial" (tropical) climates (Köppen climate type A). The $-3^{\circ} \mathrm{C}$ January (July) isotherm corresponds to a short and regularly occurring period of snow cover at mid-latitudes, and defines the border between the "warm temperate" (Köppen climate type C) and the "snow climates" (Köppen climate type D) (Köppen, 1936; Barry and Chorley, 2003).

The second and third letters of the Köppen climate consider precipitation and air temperature (Table 2). In the case of the A, C, and D climates the second letter differentiates between fully humid (f), winter dry (w), summer dry climates (s), and monsoonal ( $\mathrm{m}$, used for A climates only) climates. The third letter indicates hot (a), warm (b), cool (c), and cold (d) summers. In the case of B climates, the differentiation is between steppe (S) and desert (W) climates, each with two variants: hot (h) and cool (k). Within the E climates, one distinguishes between the tundra climate (ET) and the frost climate (EF). Recently, the Köppen system has been revised (Kottek et al., 2006) in order to allow for exact quantitative distinction between all climate types and to map their global distribution (Kottek et al., 2006; Peel et al., 2007; see http://koeppen-geiger.vu-wien.ac.at and http://www.hydrolearth-syst-sci.net/ for updated Köppen-Geiger world maps). 
Table 1. Age and stratigraphy of plant-bearing sedimentary rock formations from Iceland (after Denk et al., 2011).

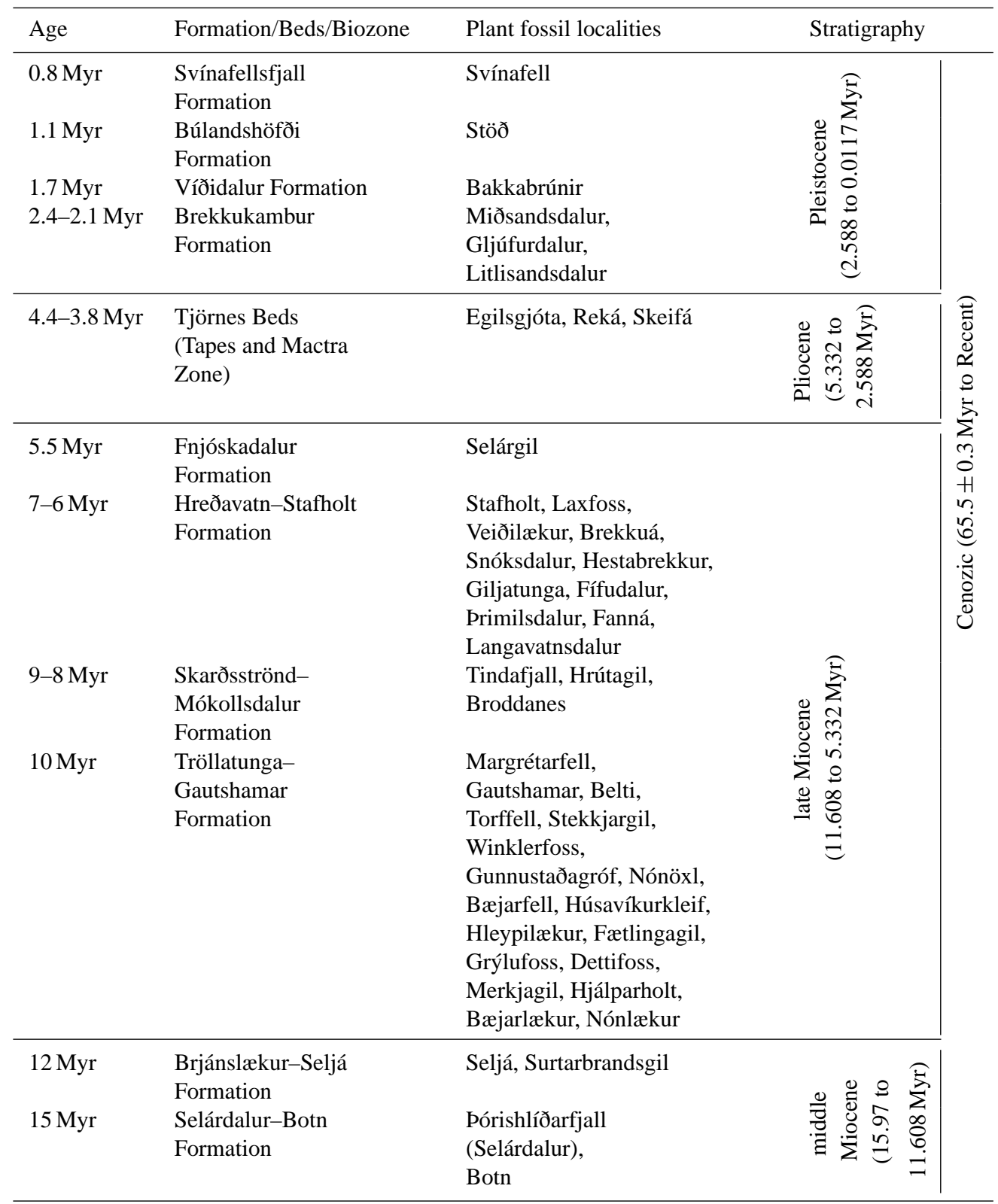

\subsection{Feasibility of Köppen climate types to describe complex climatic properties of plants}

Köppen climate types are particularly useful for describing climatic conditions, as each climate type is defined by several climate parameters that would be less or not at all informative when taken alone. For example, the warm temperate, fully humid climate with warm summers $(\mathrm{Cfb})$ describes a climate that is most characteristic of temperate broadleaved deciduous forests in both hemispheres (Walter, 1973; Schroeder, 1998). A single climate parameter, such as the mean annual temperature (MAT), is not useful for describing areas hosting this particular vegetation type. MAT within $\mathrm{Cfb}$ cli- mates of the Northern Hemisphere ranges from 5.5 to $18.9^{\circ} \mathrm{C}$ (Table 3). Köppen (1936) illustrated the problem of using single climate parameters to classify climate by two examples: New Orleans (USA) and Cairo (Egypt) have roughly the same mean annual and mean monthly temperatures but New Orleans has about 50 times the mean annual precipitation (MAP) of Cairo; Khartoum (Sudan) has about the same MAP as Verkhoyansk (northeastern Siberia) but the former has a MAT of $+22^{\circ} \mathrm{C}$ and the latter of $-50^{\circ} \mathrm{C}$ (Köppen, 1936, p. C11). 
Table 2. Key to Köppen climate types (after Kottek et al., 2006).

\begin{tabular}{|c|c|c|}
\hline $\begin{array}{l}\text { Köppen climate } \\
\text { type }\end{array}$ & Description (terminology of Köppen, 1936) & Criterion \\
\hline A & Equatorial climates (Tropische Regenklimate) & $T_{\min } \geq 18^{\circ} \mathrm{C}$ \\
\hline Af & $\begin{array}{l}\text { Equatorial rainforest, fully humid } \\
\text { (Tropische Regenklimate, Trockenzeit fehlt) }\end{array}$ & $P_{\min } \geq 60 \mathrm{~mm}$ \\
\hline Am & Equatorial monsoon & $P_{\mathrm{ann}} \geq 25 \cdot\left(100-P_{\min }\right)$ \\
\hline As & $\begin{array}{l}\text { Equatorial savannah with dry summer } \\
\text { (Tropische Regenklimate, Trockenzeit im Sommer) }\end{array}$ & $P_{\min }<60 \mathrm{~mm}$ in summer \\
\hline Aw & $\begin{array}{l}\text { Equatorial savannah with dry winter } \\
\text { (Tropische Regenklimate, Trockenzeit im Winter) }\end{array}$ & $P_{\min }<60 \mathrm{~mm}$ in winter \\
\hline B & Arid climates (Trockenklimate) & $P_{\mathrm{ann}}<10 \cdot P_{\mathrm{th}}$ \\
\hline BS & Steppe climate (Steppe) & $P_{\mathrm{ann}}>5 \cdot P_{\mathrm{th}}$ \\
\hline BW & Desert climate (Wüste) & $P_{\mathrm{ann}} \leq 5 \cdot P_{\mathrm{th}}$ \\
\hline $\mathrm{C}$ & Warm temperate climates (Warmgemässigte Regenklimate) & $-3{ }^{\circ} \mathrm{C}<T_{\min }<+18^{\circ} \mathrm{C}$ \\
\hline Cs & $\begin{array}{l}\text { Warm temperate climate with dry summer } \\
\text { (Warmgemässigtes Regenklima, Trockenzeit im Sommer) }\end{array}$ & $\begin{array}{l}P_{\mathrm{smin}}<P_{\mathrm{wmin}}, P_{\mathrm{wmax}}>3 \cdot P_{\mathrm{smin}} \\
\text { and } P_{\mathrm{smin}}<40 \mathrm{~mm}\end{array}$ \\
\hline $\mathrm{Cw}$ & $\begin{array}{l}\text { Warm temperate climate with dry winter } \\
\text { (Warmgemässigtes Regenklima, Trockenzeit im Winter) }\end{array}$ & $\begin{array}{l}P_{\mathrm{wmin}}<P_{\mathrm{smin}} \\
\text { and } P_{\mathrm{smax}}>10 \cdot P_{\mathrm{wmin}}\end{array}$ \\
\hline $\mathrm{Cf}$ & $\begin{array}{l}\text { Warm temperate climate, fully humid } \\
\text { (Warmgemässigtes Regenklima, Trockenzeit fehlt) }\end{array}$ & neither $\mathrm{Cs}$ nor $\mathrm{Cw}$ \\
\hline $\mathrm{D}$ & Snow climates (Boreale Klimate) & $T_{\min } \leq-3{ }^{\circ} \mathrm{C}$ \\
\hline Ds & $\begin{array}{l}\text { Snow climate with dry summer } \\
\text { (Boreales Klima, Trockenzeit im Sommer) }\end{array}$ & $\begin{array}{l}P_{\mathrm{smin}}<P_{\mathrm{wmin}}, P_{\mathrm{wmax}}>3 \cdot P_{\mathrm{smin}} \\
\text { and } P_{\mathrm{smin}}<40 \mathrm{~mm}\end{array}$ \\
\hline Dw & $\begin{array}{l}\text { Snow climate with dry winter } \\
\text { (Boreales Klima, Trockenzeit im Winter) }\end{array}$ & $\begin{array}{l}P_{\mathrm{wmin}}<P_{\mathrm{smin}} \text { and } \\
P_{\mathrm{smax}}>10 \cdot P_{\mathrm{wmin}}\end{array}$ \\
\hline Df & Snow climate, fully humid (Boreales Klima, Trockenzeit fehlt) & neither Ds nor Dw \\
\hline $\mathrm{E}$ & Polar climates (Schneeklimate) & $T_{\max }<+10^{\circ} \mathrm{C}$ \\
\hline ET & Tundra climate (Tundra) & $0^{\circ} \mathrm{C} \leq T_{\max }<+10^{\circ} \mathrm{C}$ \\
\hline $\mathrm{EF}$ & Frost climate (Frost ewig) & $T_{\max }<0^{\circ} \mathrm{C}$ \\
\hline $\begin{array}{l}\text { 3rd letter temperature } \\
\text { classification }\end{array}$ & Description (terminology of Köppen, 1936) & Criterion \\
\hline \multicolumn{3}{|l|}{ for B climates: } \\
\hline $\mathrm{h}$ & Hot steppe/desert & $T_{\mathrm{ann}} \geq+18^{\circ} \mathrm{C}$ \\
\hline & Cold steppe/desert & $T_{\text {ann }}<+18^{\circ} \mathrm{C}$ \\
\hline \multicolumn{3}{|l|}{ for $\mathrm{C}$ and $\mathrm{D}$ climates: } \\
\hline a & Hot summer (Sommerheisse Temperaturstufe) & $T_{\max } \geq+22^{\circ} \mathrm{C}$ \\
\hline $\mathrm{b}$ & Warm summer (Gemässigte Temperaturstufe) & not (a) and at least $4 T_{\text {mon }} \geq+10^{\circ} \mathrm{C}$ \\
\hline $\mathrm{c}$ & Cool summer (Kalte Temperaturstufe) & not (b) and $T_{\min }>-38^{\circ} \mathrm{C}$ \\
\hline $\mathrm{d}$ & Extremely continental (Kältepol) & like (c) but $T_{\min } \leq-38^{\circ} \mathrm{C}$ \\
\hline
\end{tabular}

$P=$ accumulated precipitation, $T=$ near-surface $(2 \mathrm{~m})$ temperature;

$P_{\mathrm{smin}}=$ minimum monthly precipitation for the summer half-year, $P_{\mathrm{smax}}=$ maximum monthly precipitation for the summer half-year;

$P_{\mathrm{wmin}}$ minimum monthly precipitation for the winter, $P_{\mathrm{wmax}}=$ maximum monthly precipitation for the winter;

$P_{\mathrm{th}}=$ dryness threshold for B climates in mm. If $P_{\mathrm{W}} \geq 2 / 3 \cdot P_{\mathrm{ann}}$, then $P_{\mathrm{th}}=2 \cdot T_{\mathrm{ann}}$. If $P_{\mathrm{S}} \geq 2 / 3 \cdot P_{\mathrm{ann}}$, then $P_{\mathrm{th}}=2 \cdot T_{\mathrm{ann}}+28$. If $P_{\mathrm{W}}$ and $P_{\mathrm{S}}<2 / 3 \cdot T_{\mathrm{ann}}$, then

$P_{\text {th }}=2 \cdot T_{\text {ann }}+14$

$T_{\text {mon }}=$ mean monthly near-surface $(2 \mathrm{~m})$ temperature.

\subsection{Using Köppen climate types to detect past climate change}

The direct correlation of Köppen climate types (Table 2; Köppen, 1936; Kottek et al., 2006) to major vegetation types
(Table 4; Walter, 1973; Schroeder, 1998) makes them useful for reconstructing past climates based on plant fossil assemblages (Köppen and Wegener, 1924; Wegener, 1929). Increasingly mild or harsh climate conditions and corresponding changes in vegetation are reflected by progression 
Table 3. Ranges of individual climate parameters of selected Köppen climate types for the Northern Hemisphere (compiled from Lieth et al., 1999).

\begin{tabular}{|c|c|c|c|c|c|c|c|c|}
\hline \multicolumn{9}{|l|}{ Equatorial and dry climates } \\
\hline Climate type & Af & Am & As & Aw & BSh & $\mathrm{BSk}$ & BWh & BWk \\
\hline Number of stations & 66 & 51 & 23 & 126 & 69 & 205 & 110 & 48 \\
\hline Min of elevation [m a.s.1.] & 2 & 1 & 1 & 1 & 3 & -15 & -15 & -20 \\
\hline Max of elevation [m a.s.1.] & 740 & 1200 & 522 & 1291 & 2066 & 3650 & 1478 & 3174 \\
\hline Min of $P_{\mathrm{ann}}\left[\mathrm{mma}^{-1}\right]$ & 1448 & 1284 & 718 & 773 & 189 & 108 & 1 & 16 \\
\hline Max of $P_{\text {ann }}\left[\mathrm{mma}^{-1}\right]$ & 4608 & 5537 & 1884 & 2482 & 816 & 559 & 378 & 230 \\
\hline Min of $T_{\mathrm{ann}}\left[{ }^{\circ} \mathrm{C}\right]$ & 23 & 20 & 23 & 22 & 18 & -4 & 18 & -2 \\
\hline $\operatorname{Max}$ of $T_{\mathrm{ann}}\left[{ }^{\circ} \mathrm{C}\right]$ & 27 & 28 & 28 & 29 & 28 & 18 & 30 & 18 \\
\hline Min of $\Delta T\left[{ }^{\circ} \mathrm{C}\right]$ & 1 & 1 & 2 & 1 & 2 & 5 & 5 & 18 \\
\hline Max of $\Delta T\left[{ }^{\circ} \mathrm{C}\right]$ & 11 & 12 & 13 & 15 & 30 & 44 & 26 & 46 \\
\hline \multicolumn{9}{|l|}{ Warm-temperate climates } \\
\hline Climate type & $\mathrm{Cfa}$ & $\mathrm{Cfb}$ & $\mathrm{Cfc}$ & Csa & $\mathrm{Csb}$ & $\mathrm{Csc}$ & Cwa & $\mathrm{Cwb}$ \\
\hline Number of stations & 567 & 226 & 12 & 94 & 59 & 1 & 64 & 21 \\
\hline Min of elevation [m a.s.1.] & -9 & -4 & 1 & -13 & 3 & 23 & 5 & 1598 \\
\hline Max of elevation [m a.s.1.] & 1725 & 2339 & 304 & 1326 & 2367 & 23 & 1599 & 3488 \\
\hline Min of $P_{\mathrm{ann}}\left[\mathrm{mma}^{-1}\right]$ & 393 & 327 & 693 & 354 & 418 & 486 & 533 & 474 \\
\hline Max of $P_{\text {ann }}\left[\mathrm{mma}^{-1}\right]$ & 4019 & 2968 & 1645 & 2019 & 2274 & 486 & 2866 & 2843 \\
\hline Min of $T_{\mathrm{ann}}\left[{ }^{\circ} \mathrm{C}\right]$ & 10 & 6 & 3 & 10 & 8 & 3 & 11 & 5 \\
\hline Max of $T_{\mathrm{ann}}\left[{ }^{\circ} \mathrm{C}\right]$ & 23 & 19 & 7 & 26 & 17 & 3 & 26 & 17 \\
\hline $\operatorname{Min}$ of $\Delta T\left[{ }^{\circ} \mathrm{C}\right]$ & 6 & 4 & 7 & 8 & 5 & 13 & 6 & 4 \\
\hline $\operatorname{Max}$ of $\Delta T\left[{ }^{\circ} \mathrm{C}\right]$ & 29 & 24 & 15 & 29 & 23 & 13 & 29 & 20 \\
\hline \multicolumn{9}{|c|}{ Snow climates (warm and hot summers) } \\
\hline Climate type & Dfa & Dfb & Dsa & Dsb & Dwa & Dwb & & \\
\hline Number of stations & 165 & 356 & 1 & 9 & 30 & 26 & & \\
\hline Min of elevation [m a.s.1.] & 17 & 3 & 1156 & 523 & 4 & 65 & & \\
\hline Max of elevation [m a.s.1.] & 1292 & 2393 & 1156 & 1667 & 1065 & 3837 & & \\
\hline Min of $P_{\mathrm{ann}}\left[\mathrm{mma}^{-1}\right]$ & 347 & 259 & 368 & 277 & 407 & 271 & & \\
\hline Max of $P_{\text {ann }}\left[\mathrm{mma}^{-1}\right]$ & 1137 & 1429 & 368 & 785 & 1634 & 728 & & \\
\hline Min of $T_{\mathrm{ann}}\left[{ }^{\circ} \mathrm{C}\right]$ & 6 & -1 & 11 & 4 & 3 & -3 & & \\
\hline Max of $T_{\mathrm{ann}}\left[{ }^{\circ} \mathrm{C}\right]$ & 12 & 9 & 11 & 9 & 12 & 9 & & \\
\hline Min of $\Delta T\left[{ }^{\circ} \mathrm{C}\right]$ & 25 & 17 & 27 & 19 & 27 & 18 & & \\
\hline $\operatorname{Max}$ of $\Delta T\left[{ }^{\circ} \mathrm{C}\right]$ & 35 & 40 & 27 & 27 & 43 & 48 & & \\
\hline \multicolumn{9}{|c|}{ Snow climates (cool summers, extremely continental) and tundra climate } \\
\hline Climate type & Dfc & Dfd & Dsc & Dwc & Dwd & ET & & \\
\hline Number of stations & 151 & 8 & 8 & 39 & 1 & 70 & & \\
\hline Min of elevation [m a.s.1.] & 1 & 45 & 24 & 56 & 400 & 2 & & \\
\hline Max of elevation [m a.s.l.] & 2743 & 858 & 4053 & 3950 & 400 & 4701 & & \\
\hline Min of $P_{\mathrm{ann}}\left[\mathrm{mma}^{-1}\right]$ & 145 & 153 & 165 & 193 & 283 & 67 & & \\
\hline Max of $P_{\mathrm{ann}}\left[\mathrm{mma}^{-1}\right]$ & 3515 & 488 & 1676 & 720 & 283 & 3450 & & \\
\hline Min of $T_{\mathrm{ann}}\left[{ }^{\circ} \mathrm{C}\right]$ & -13 & -16 & -11 & -10 & -13 & -20 & & \\
\hline Max of $T_{\mathrm{ann}}\left[{ }^{\circ} \mathrm{C}\right]$ & 5 & -10 & 3 & 4 & -13 & 6 & & \\
\hline Min of $\Delta T\left[{ }^{\circ} \mathrm{C}\right]$ & 14 & 53 & 16 & 16 & 60 & 9 & & \\
\hline Max of $\Delta T\left[{ }^{\circ} \mathrm{C}\right]$ & 56 & 63 & 53 & 53 & 60 & 45 & & \\
\hline
\end{tabular}

of Köppen climate types, which is also seen as a vertical gradient in mountain ranges (Table 5). Non-generalist taxa, which are restricted to particular vegetation types (Schroeder, 1998), are also restricted to certain Köppen climate types. For example, all modern species of beech trees (Fagus L.) are typical elements of the deciduous broadleaved forests of the mid-latitudes of the Northern Hemisphere ("deciduous nemoral forests", Table 4). Beeches are widespread across the north-temperate regions, but occur predominantly under a Cfb climate, as was already recognized by Köppen (1936), 
Table 4. Vegetation zones of the Earth and their corresponding Köppen climate types.

\begin{tabular}{|c|c|c|}
\hline Vegetation zones after Walter (1973) & $\begin{array}{l}\text { Climax vegetation zones after Schroeder (1998) } \\
\text { (thermal zone and hygric variant) }\end{array}$ & $\begin{array}{l}\text { Köppen climate types (Köppen, 1936; Kottek } \\
\text { et al., 2006) (letter code: main climate type, annual } \\
\text { distribution of precipitation and temperature) }\end{array}$ \\
\hline \multicolumn{3}{|l|}{ I. Tropical and subtropical zones } \\
\hline $\begin{array}{l}1 \text { Evergreen, rainforests of the lowlands and } \\
\text { mountain-sides (cloud forests) }\end{array}$ & 1 Tropischer Regenwald (Tropical, humid) & Af (Equatorial, fully humid) \\
\hline 2 Semi-evergreen and deciduous forests & $\begin{array}{l}2 \text { Regengrüner Wald (mit Savanne) } \\
\text { (Tropical, semi-humid) }\end{array}$ & Aw (Equatorial, winterdry) \\
\hline $\begin{array}{l}\text { 2a Dry woodlands, natural savannas or } \\
\text { grassland pro parte (p.p.) }\end{array}$ & $\begin{array}{l}3 \text { Eurytropische Trockengehölze } \\
\text { (Tropical, oreotropical, meridional, austral; arid) }\end{array}$ & BSh (Arid, steppe, hot arid) \\
\hline $\begin{array}{l}\text { 2a Dry woodlands, natural savannas or } \\
\text { grassland p.p. }\end{array}$ & 8 Pampa (Austral; semi-arid and arid) & $\begin{array}{l}\text { BSk (Arid, steppe, cold arid), } \\
\text { Cwb (Warm temperate, winter dry, warm summer) }\end{array}$ \\
\hline $\begin{array}{l}3 \text { Hot semi-deserts and deserts, polewards } \\
\text { up to latitude of } 35^{\circ} \mathrm{N}\end{array}$ & $\begin{array}{l}4 \text { Eurytropische Wüste (Halb- und Vollwüste) } \\
\text { (Tropical, oreotropical, meridional, austral; arid) }\end{array}$ & BWh (Arid, desert, hot arid) \\
\hline \multicolumn{3}{|l|}{ II. Temperate and Arctic zones } \\
\hline 4 Sclerophyllous woodlands with winter rain & 7 Hartlaubwald (Meridional and austral, semi-humid) & $\begin{array}{l}\text { Csa (Warm temperate, summer dry, hot summer), } \\
(\mathrm{Csb}, \mathrm{Cfa}, \mathrm{Cfb}, \mathrm{BSh}, \mathrm{Cwa})^{\mathrm{a}}\end{array}$ \\
\hline 5 Moist warm temperature woodlands & 6 Lorbeerwald (Meridional and austral, humid) p.p. & $\begin{array}{l}\text { Cfa (W. temp., fully humid, hot summer), } \\
\text { Cwa (W. temp., winter dry, hot s.), Cwb, Cfb }\end{array}$ \\
\hline 6 Deciduous (nemoral) forests p.p. & $\begin{array}{l}9 \text { Sommergrüner Laubwald: humid/semi-humid } \\
\text { (Nemoral, humid and semi-humid) }\end{array}$ & $\begin{array}{l}\text { Cfa, Cfb, Dfa (Snow, fully humid, hot s.), } \\
\text { Dfb, Cwa, Dwa, Dwb, (Csb), (Cfc) })^{b}\end{array}$ \\
\hline 6 Deciduous (nemoral) forests p.p. & 6 Lorbeerwald (Meridional and austral, humid) p.p. & $\mathrm{Cfa}, \mathrm{Cwa}, \mathrm{Cwb},(\mathrm{Cfb})^{\mathrm{c}}$ \\
\hline 7 Steppes of the temperate zone & 12 Steppe (Nemoral, boreal, semi-arid and arid) & BSk \\
\hline 7a Semi-deserts and deserts with cold winters & 13 Nemorale Wüste (Nemoral, boreal, semi-arid and arid) & BWk (Arid, desert, cold arid) \\
\hline 8 Boreal coniferous zone p.p. & 10 Nemoraler Nadelwald (Nemoral, semi-humid) p.p. & $\begin{array}{l}\text { Dfb } \rightarrow \text { Dfc (Snow, fully humid, cool summer), } \\
\mathrm{Csb}^{\mathrm{d}} \text { and } \mathrm{Cfb}\end{array}$ \\
\hline 8 Boreal coniferous zone p.p. & 14 Dunkle Taiga (Boreal, humid) & Dfc \\
\hline 8 Boreal coniferous zone p.p. & 15 Helle Taiga (Boreal, semi-humid) & Dfc, Dfd (Snow, fully humid, extremely continental) \\
\hline 9 Tundra & $\begin{array}{l}16 \text { Polar-Alpine Tundra/Wüste } \\
\text { (Arctic, Antarctic, Alpine; humid to arid) }\end{array}$ & ET \\
\hline 10 Mountains p.p. & $\begin{array}{l}5 \text { Oreotropischer Wald } \\
\text { (Oreotropical, humid and semi-humid) p.p. }\end{array}$ & $\mathrm{Cfb}, \mathrm{Csb}, \mathrm{Cwb}$ \\
\hline Transitional between $4 / 10$ and $7 / 7 a$ & $\begin{array}{l}11 \text { Nemorale Trockengehölze } \\
\text { (Dry woodlands of the temperate zone) }\end{array}$ & Chiefly transition between B and Cs climates \\
\hline
\end{tabular}

a Australia East Coast;

${ }^{\mathrm{b}}$ Humid coastal broadleaved deciduous forests: subarctic birch forest of Iceland, western Norway, Kamchatka;

c Australia East Coast, New Zealand;

d Pacific North America.

commonly forming pure stands. In the overall warmer Cfa climates (warm temperate, fully humid with hot summers, Table 2) of eastern North America, the Black Sea region, and central China, beech trees are found exclusively as accessory elements in mixed mesophytic forests (Wang, 1961; Maycock, 1994; Cao, 1995; Peters, 1997). In the more frostprone Dfb climates (snow, fully humid with warm summers; Table 2), beech trees are co-dominants with shade-tolerant conifers such as Abies Mill. and Tsuga Carrière and few other broadleaved deciduous trees (Maycock, 1994). The genus' northern limit in North America and Japan (Maycock, 1994) coincides with the northern limit of the Dfb climate zone (Grimm and Denk, 2012). Fagus is not found in any other climate type (Shen, 1992; Peters, 1997).

Distribution ranges of other taxa cover different combinations of Köppen climate types. Hence, plant assemblages can be characterized and compared by scoring the Köppen climate types covered by their constituent elements. Using the actualistic principle, the assumption that modern conditions can be extrapolated to the geological past, extinct plant as- semblages can be characterized in the same way and climatic shifts detected.

\subsection{Characterization of modern taxa using Köppen climate types ('Köppen signatures")}

To establish Köppen signatures of individual plant taxa, we used distribution data from numerous sources (Hegi, 1923, 1928, 1966a, b, 1974, 1981a, b, 1984; Ohwi, 1965; Browicz and Zieliński, 1982, 1982-1994, 1984; Browicz, 1986; Farjon, 1990; Thompson et al., 1999a, b, 2001, 2006; Fang et al., 2009; Anderberg and Anderberg, 2010; Flora of China, 2010) to identify the Köppen climate types to which they belong. The updated Köppen-Geiger World Map of Kottek et al. (2006; including a kmz-file for Google Earth) provided the basis for the mapping of climate types. The resolution of both the available distribution data and the KöppenGeiger map necessitated some extrapolations. For taxa with a restricted altitudinal distribution, we established altitudinal progressions of Köppen climate types based on climate stations (Lieth et al., 1999) from the corresponding regions 
Table 5. Vertical progression of Köppen climate types in Northern Hemisphere mountain ranges.

\begin{tabular}{llll}
\hline Lowland & Mid-elevation & High elevation & Example \\
\hline $\mathrm{Cfa}$ & $\mathrm{Cfb}$ & Dfb $>$ Dfc (ET) & S. Caucasus, Appalachian Mts. \\
$\mathrm{Cfb}$ & Dfb & Dfc (ET) & E. Alps \\
$\mathrm{Cfc}$ & Dfc (ET) & ET & W. Scandinavia, Iceland \\
\hline $\mathrm{Cwa}$ & $\mathrm{Cwb}$ & Dwb/Dwc (ET) & Himalaya Mts. \\
\hline $\mathrm{Csa} / \mathrm{Cfa}$ & $\mathrm{Cfb}$ & BSk & Pyrenees \\
$\mathrm{Csa}$ & $\mathrm{Csb}$ & ? BSk & Pico Almazor (C. Spain), Atlas Mts. \\
$\mathrm{Csa}$ & $\mathrm{Cfa}$ & $\mathrm{Cfb}$ & Apennine Mts. \\
$\mathrm{Csa}$ & $\mathrm{Dsa}$ & Dsb & NW. Alborz Mts. \\
\hline BSk & Dsa & Dsb & SC. Alborz Mts. \\
$\mathrm{BSk}$ & $\mathrm{Dfb}(\mathrm{Cfb})$ & Dfc (ET) & Rocky Mts. (Colorado, Mt. Elbert) \\
BSh & Csa & Csb, Csc (ET) & W. Hindukush (Tirich Mir) \\
BSh & Cfa/Cwa & Cfb, Dfc/ET & Nanga Parbat \\
\hline
\end{tabular}

* Highest peak: Dfb.

(ES 7 in Grimm and Denk, 2012). For example, in southern Japan (Kyushu and Shikoku islands, western part of Honshu) the predominant Cfa climate indicated in the map (Kottek et al., 2006) is replaced by a Cfb climate at $\sim 1000 \mathrm{~m}$ above sea level, which is not represented on the map because no climate stations are available at high elevations. In central Honshu the transition from Cfa to $\mathrm{Cfb}$ occurs at $\sim 500 \mathrm{~m}$, and at $\sim 1000 \mathrm{~m}$ the $\mathrm{Cfb}$ climate is replaced by the Dfb climate, which characterizes the central high mountain range of eastern Honshu and most of the island of Hokkaido (Lieth et al., 1999; Kottek et al., 2006). The grid size used by Kottek et al. (2006) does not resolve the narrow strip of Cfb between the lowlands (Cfa) and mountains (Dfb) of eastern Honshu. The altitudinal distribution of Fagus crenata Blume in Japan (Maycock, 1994) is strongly correlated to the altitudinal distribution of the $\mathrm{Cfb}$ and Dfb climates; hence, this taxon was not scored for $\mathrm{Cfa}$ in addition to $\mathrm{Cfb}$ and $\mathrm{Dfb}$ in contrast to the North American species F. grandifolia Ehrh., which extends to sea level in northern Florida and Lousiana (Cfa, Dataset S1 in the Supplement). Similar extrapolations were made for high-mountain taxa of western Eurasia and eastern Asia. The detailed information regarding reference and scored Köppen climate types, i.e. Köppen signatures, for all (modern) taxa are provided in the ClimGrim database (v. 0.2, www.palaeogrimm.org/data; a copy of the database dating from 30/11/2012 is included in the electronic supplement to this article).

\subsection{Representation of fossil taxa and the modern flora of Iceland by Köppen climate types}

Using the actualistic principle, one can infer climate conditions for a plant fossil assemblage by characterizing the climate conditions under which potential modern analogues (PMA) of fossil plant taxa can thrive.
Firstly, for all fossil taxa identified to genus level or below, one or more PMA were determined based on the systematic affinities of the 342 fossil taxa from Iceland with modern plant taxa (Denk et al., 2011). In the case of genera, determination of PMA is straightforward: all modern species of the genus constitute potential PMA. The number of PMA can be narrowed down in the case of large genera. Due to the geographic position and geotectonic setting of Iceland, PMA thriving in eastern North America (and Greenland), the Arctic, and (northern) Europe provide reasonable PMA for fossil taxa, in particular for the younger floras. For example, in the case of many herbaceous species, all taxa with distributions recorded in Virtuella Floran (Anderberg and Anderberg, 2010) were considered as PMA. In the older floras some taxa are found that are members of genera that went extinct in Europe and currently have a disjunct eastern AsianNorth American distribution (e.g. Carya Nutt., Liriodendron L., Magnolia L., Parthenocissus Planch., Sassafras J. Presl). In addition, very few taxa went extinct in Europe and North America (Ginkgo L.) or in Europe and eastern Asia (Comptonia L'Hér.). In these cases, all northern hemispheric representatives of the respective genera were considered as PMA (distribution data based on Hegi, 1923, 1928, 1966a, b, 1974, 1981a, b, 1984; Ohwi, 1965; Browicz and Zieliński, 1982, 1982-1994, 1984; Browicz, 1986; Farjon, 1990; Thompson et al., 1999a, b, 2001, 2006; Fang et al., 2009; Anderberg and Anderberg, 2010; Flora of China, 2010).

Below the genus level, the determination of PMA followed Denk et al. (2011). For only a few cases are phylogenetic frameworks available to establish relationships between fossil and particular modern species or intrageneric groups, i.e. Acer L. sect. Acer (Grimm et al., 2007), Fagus (Denk et al., 2005a; Denk and Grimm, 2009a), and Quercus L. (Denk and Grimm, 2009b, 2010). In some cases, exact affinities can be established by means of epidermal features of 
the leaves, e.g. Acer (Walther, 1972; Friedrich and Símonarson, 1982), Cathaya (Denk et al., 2011), and Cryptomeria D. Don (Denk et al., 2005b), or pollen ornamentation, Quercus Group Quercus and Lobatae (Denk and Grimm, 2009b; Denk et al., 2010), and Rhododendron L. subsect. Pontica (Denk et al., 2011). In all other cases, affinities rely on similarities of leaf morphology and morphology of reproductive structures (Denk et al., 2011). In some cases, more than one PMA was determined for a fossil taxon. If so, all Köppen climate types covered by these PMA were used to establish the Köppen signature of the fossil taxon (Dataset S1, sheet no. 3).

Secondly, for each sedimentary formation, the count of climate types realized by all its (fossil) constituents was established in order to document changes in the frequencies of plants representing particular climate types. Since a single fossil taxon may count for more than one Köppen climate type, and since the total number of scorable fossil taxa differs among the sedimentary formations, absolute values, i.e. the sum of fossil taxa scored for a certain Köppen climate type per sedimentary rock formation, were scaled using the maximum number of fossil taxa scorable for a single formation, i.e. 43 taxa (Dataset S1).

The same procedure was performed for the modern flora of Iceland; monocots were not considered, because they are absent or very rare and not precisely identifiable in the fossil record (Dataset S2 in the Supplement). Plants that thrive both under a Cfc (warm temperate, fully humid with cool summers) and ET (tundra) climate in Iceland and along the southern coast of Greenland, but otherwise are absent from ET climates, were not labelled as ET (e.g. Bartsia alpina L., Fig. A1). The coastal, climatically favoured ET climates of northern Iceland and southern Greenland approach the Cfc climate type (see also Peel et al., 2007) and may, in the near future, be replaced by Cfc climates (Rubel and Kottek, 2010). The extension into a warm type of ET climate in Iceland reflects the overall tendency of plants to extend their ranges into neighbouring climate types under particular conditions (e.g. edaphic ones). For the Cfc climate type, several adjacent climate types (Fig. 1) are commonly shared by plant taxa, i.e. a plant species will not occur only in a Cfc climate but also in ET, $\mathrm{Cfb}$, and Dfc (snow, fully humid with cool summers) climates (Dataset S2). Likewise, an altitudinal progression of Köppen climate types occurs (Table 5).

\subsection{Categorization of fossil taxa as elements of major vegetation zones}

In a second step, each scored taxon was categorized as "meridio-nemoral", "nemoral", "boreal", and "Arcticalpine" (Fig. 2) using the nomenclature and vegetation maps of the world from Walter (1973) and Schroeder (1998).

Plants thriving under $\mathrm{Cfa}$ and/or $\mathrm{Cwa} / \mathrm{Cwb}$ (warm temperate, winter dry with hot or warm summers) and Csa/Csb (warm temperate, summer dry with hot or warm summers)

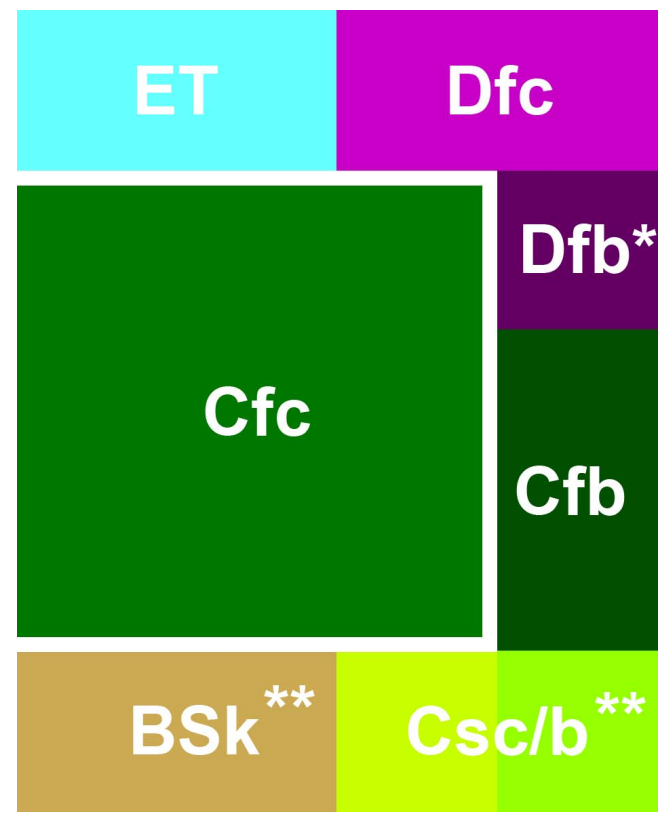

Fig. 1. Cfc Köppen climate type, typical of the coastal regions of modern Iceland, and its neighbouring climate types. Note that plant taxa typical of a Cfc climate commonly occur at least in several further, adjacent climate types. $\left(^{*}\right)$ No direct contact, $\left({ }^{* *}\right)$ direct contact only in Southern Hemisphere.

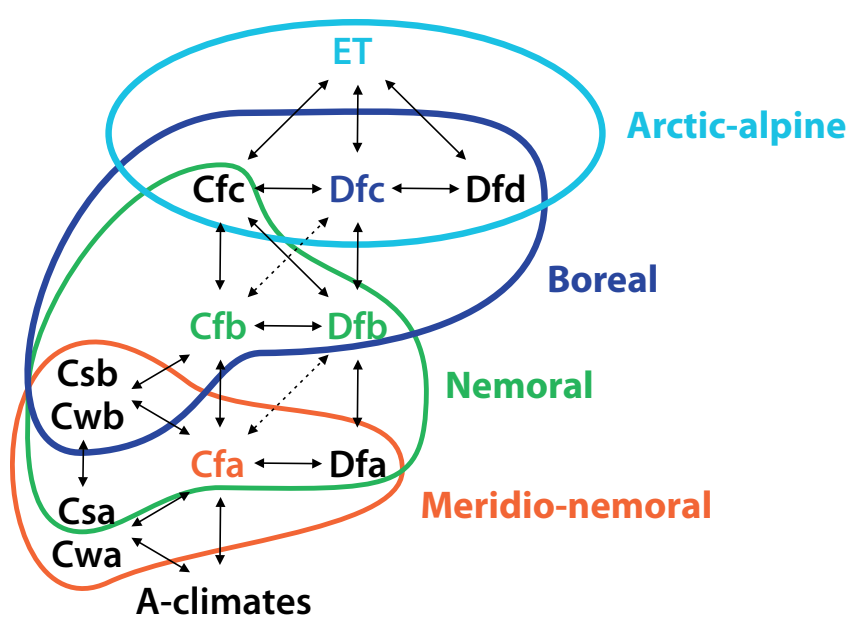

Fig. 2. Circumscription of meridio-nemoral, nemoral, boreal and Arctic-alpine elements by Köppen climate types (see also Table 4).

climate types but not under a Cfb climate or harsher climates were categorized as meridio-nemoral elements (according to Schroeder, 1998). These plants are typical elements of Northern Hemisphere broadleaved deciduous forests of the nemoral zone, but may extend into the warmer laurel forests of the meridional zone (Walter, 1973; Schroeder, 1998).

Nemoral elements are plants that typically thrive under $\mathrm{Cfb}$, Dfb, Cwb, and Dwb, (snow, winter dry with warm summers) and possibly extend into warmer "a" variants of these 
climate types or Cfc climates (cool summers but mild winters). These elements dominate today's northern temperate forest regions.

Boreal elements are plants typically found in Cfc, Dfc, and Dfd (snow, fully humid with cold summers) climates (and their hygric variants Csc, Dsc, Dsd, summer dry, and Cwc, Dwc, Dwd, winter dry with cool or cold summers) and possibly extend into $\mathrm{Cfb} / \mathrm{Dfb}$ and related climates but are absent from ET and Cfa, Csa, and Cwa climates. The boreal zone typically comprises regions in the world that are dominated by conifer forests (Walter, 1973; Schroeder, 1998).

Arctic-alpine elements are plants thriving under an ET climate and extend into Cfc, Dfc, and Dfd climates (and their hygric variants), but not in climates with warm or hot summers (e.g. Cfb, Dfb). This group comprises species that show the typical Arctic-alpine disjunction (e.g. Ranunculus glacialis L., cf. Fig. A3), whereas others may be confined to the boreal and Arctic zones but have closely related species in the Alps (e.g. Erigeron borealis (Vierh.) Simmons and $E$. neglectus Kern. ex Nyman).

All other taxa were categorized as "generalists". These can cope with a large variety of climate types (for example, Cfa to Dfc) and include cosmopolitan herbaceous plant taxa.

For fossil assemblages from each sedimentary formation, the representation of these five ecological groups (vegetation categories; Datasets S1, S2) was established in order to observe changes in their frequencies within floras over the course of the past 15 million years.

\section{Results: vegetation and climate development in Iceland during the last $15 \mathrm{Myr}$}

\subsection{Vegetation development}

The oldest plant-bearing sedimentary rocks in Iceland were deposited $\sim 15 \mathrm{Myr}$ and fall within the MMCO (Denk et al., 2011). A combined analysis of macrofossils and palynomorphs from lowland and mountainous settings indicate the presence of lowland riparian and swamp forests dominated by Cupressaceae (Glyptostrobus Endl.) and warm temperate angiosperms such as Aesculus L., Platanus L., Pterocarya Kunth, and the woody vine Parthenocissus at that time. Upland forests were dominated by Fagus with an admixture of conifers - such as Cathaya, Sequoia Endl. and, higher up, Cryptomeria - and a wealth of other mesothermal tree species including evergreens such as Ilex L. and Rhododendron (Fig. 3a-h). In $\sim 12 \mathrm{Myr}$ strata, the diversity of recovered fossil plant taxa increases markedly from 35 to 66 taxa; in addition to the taxa recorded from the older formation, lianas such as Smilax L. and lowland taxa with current eastern Asian-North American disjunctions are recorded (e.g. Liriodendron, Magnolia, Sassafras). A major floristic change is encountered in the $\sim 10 \mathrm{Myr}$ formation, which hosts the most taxon-rich flora from Iceland, com-

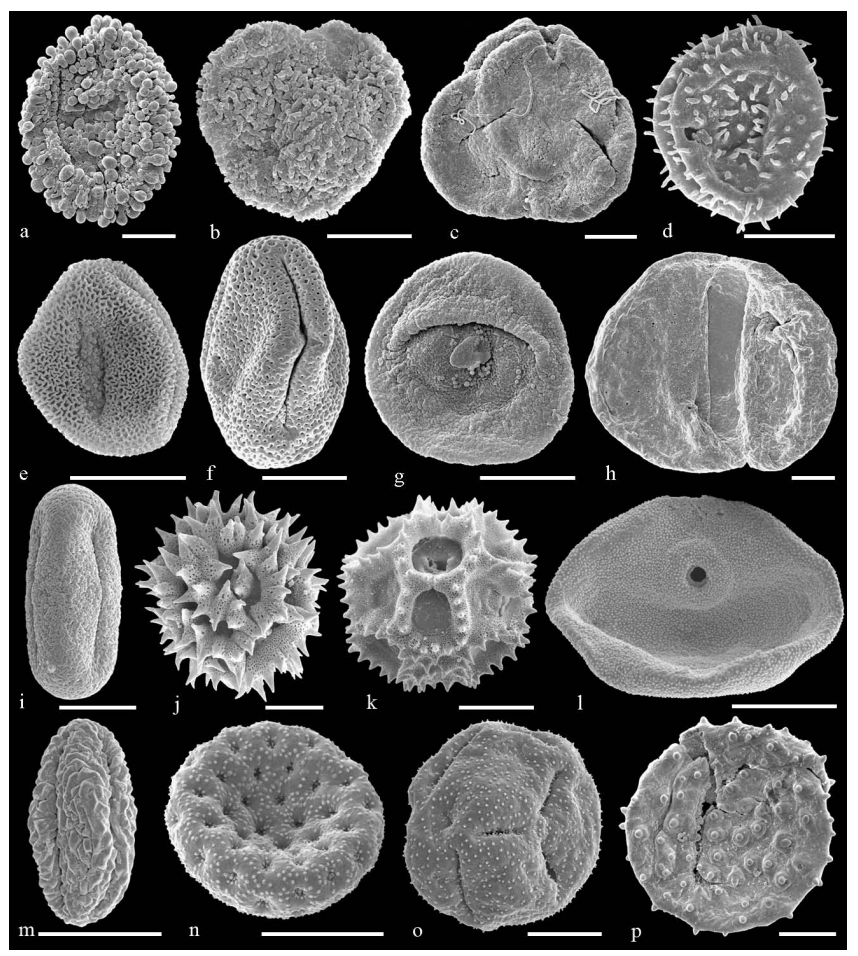

Fig. 3. Floristic turnover in Iceland as illustrated by characteristic pollen types from the 15-0.8 Myr sedimentary rock formations. (a-h) Pollen of predominantly woody, warmth-loving plants, 15 and 12 Myr. (a) Ilex sp., 12 Myr. (b) Viburnum sp., 12 Myr. (c) Rhododendron aff. ponticum L., $12 \mathrm{Myr}$. (d) Lemna sp., $12 \mathrm{Myr}$. (e) Platanus subgenus Platanus, 15 Myr. (f) Parthenocissus sp., 15 Myr. (g) Sequoia sp., 15 Myr. (h) Cathaya sp., 15 Myr. (i-p) Pollen of herbaceous plants, $10 \mathrm{Myr}$ and younger formations. (i) Apiaceae, 10 Myr. (j) Asteraceae, 10 Myr. (k) Asteraceae, 1.1 Myr. (l) Poaceae, 0.8 Myr. (m) Fragaria sp., 1.7 Myr. n. Chenopodium sp., 10 Myr. (o) Ranunculus sp., 10 Myr. (p) Valeriana sp., 3.8 Myr.

prising 99 taxa (Dataset S2). Whereas 4 of 66 taxa were herbaceous in the $\sim 12 \mathrm{Myr}$ floras, one-third of all taxa in the $\sim 10 \mathrm{Myr}$ formation are herbaceous (Fig. 3i-p). This increase in herbaceous plants is accompanied by the first occurrence of small-leaved Ericaceae typical of the modern tundra vegetation in Iceland (Vaccinium L., Arctostaphylos Adans.) and boreal conifers such as Larix Mill. Nevertheless, several warmth-loving elements persisted, including Platanus, Pterocarya, and Tilia L., and new elements are recorded (Ginkgo). Floras preserved in strata between $\sim 10$ and 3.6 Myr reflect stepwise cooling; Fagus persisted until 7-6 Myr and Quercus until $~ 5.5 \mathrm{Myr}$, whereas the evergreen, large-leaved Rhododendron aff. ponticum L. ranges from the oldest to the 3.8-3.6 Myr floras. At 4.4-3.6 Myr, small-leaved Salicaceae occur for the first time. The second major reorganization of the vegetation is recorded in floras from the Pliocene-Pleistocene transition. Temperate woody elements are not found in any of the Pleistocene floras, which are essentially similar to the modern flora of Iceland. 


\subsection{Köppen climate type distribution and frequency in modern flowering plants of Iceland}

Naturally, most climate types realized in the modern flora of Iceland are those of the present Cfc and ET types (Kottek et al., 2006; Peel et al., 2007) and the climate types to which the latter are directly connected (Fig. 4, bottom line). The higher proportion of $\mathrm{Cfc}$ in the distribution of climate types as compared to the lower proportion of ET types is due to the fact that only one-third of the modern flowering plants in Iceland (monocots excluded) are typical ET plants. At the same time, most of the ET plants are also found in milder Cfc, Cfb, and Dfc climates. By contrast, there are only a few taxa that extend their ranges into warmer climates with hot summers ("a" climates); these are generalists with vast modern distribution ranges and are more typically herbaceous rather than woody plants.

The distribution of Köppen climate types based on the modern flora of Iceland serves as a reference point for comparison with the fossil floras.

\subsection{Climate development inferred from Köppen signatures}

In order to quantify climatic signals captured in the fossil floras, we transformed modern distribution ranges of PMA of fossil taxa into "Köppen signatures", and observed changes through time (Fig. 5). No change is recorded between 15 and $12 \mathrm{Myr}$. During this period, warm temperate, fully humid climates with hot or warm summers $(\mathrm{Cfa}, \mathrm{Cfb})$ are well represented. Meridio-nemoral and nemoral elements (Walter, 1973; Schroeder, 1998) dominated the vegetation at this time (Fig. 6). In contrast, climates with cool summers and cold winters (Cfc, Dfc), as well as polar tundra (ET) climates, are barely covered by the PMA, suggesting that boreal and Arctic-alpine elements played only a minor role during that time and were confined to highest elevations. The onset of large-scale Northern Hemisphere glaciation in the Miocene as recorded from the central Arctic Ocean and the northern Barents Sea after $\sim 15 \mathrm{Myr}$ (Frank et al., 2008; Knies and Gaina, 2008) and major growth of the East Antarctic Ice Sheet starting between 15 and 14 Myr (Zachos et al., 2001; Lewis et al., 2008) did not profoundly impact the subarctic North Atlantic region (Fig. 5). This is in stark contrast to the situation in subarctic North America, where vegetation changes closely mirror the MMCT (Wolfe, 1994; White et al., 1997). A clear change between the 15 and $12 \mathrm{Myr}$ and the younger floras in Iceland is expressed by the marked increase of Cfc- and Dfc-tolerant taxa ("I" in Fig. 5) and the gradual loss of Cfa and Cwa taxa (Fig. 4). Three changes towards milder conditions are evident in the late Miocene between 10 and 9-8 Myr ("II", Fig. 5) as well as in the Pleistocene and Holocene (between 1.7 and $1.1 \mathrm{Myr}$, and between $0.8 \mathrm{Myr}$ and the present). Although the Miocene (9-8 Myr) shift may be influenced by the local environmental factors

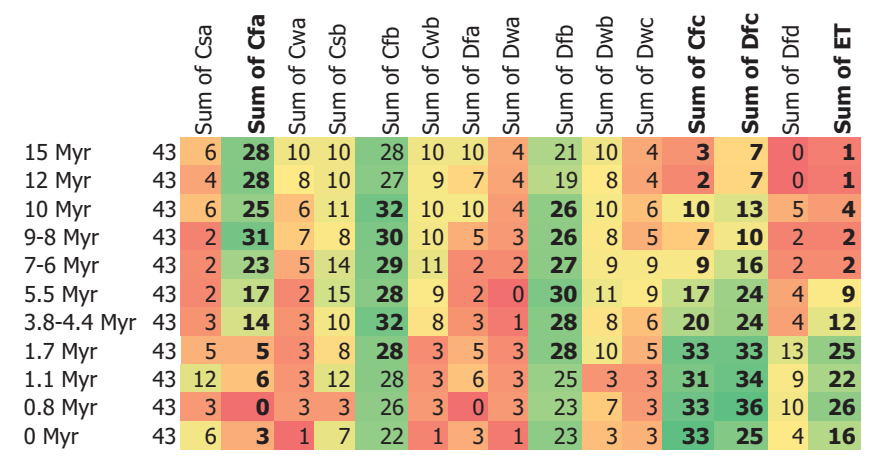

Fig. 4. The heat map shows the sum of fossil taxa with modern analogues occurring in certain Köppen climate types. Number of taxa scoring for particular climate types was scaled to 43 for all rock units.

(fossil floras derived from vegetation flanking caldera lakes; Denk et al., 2011), the younger warming events likely reflect broader Pleistocene climate dynamics. From the late Miocene to Pliocene (7-6 Myr to 5.5 Ma; "III" in Fig. 5) marked cooling is evidenced by the further increase of Cfc-, Dfc-, and ET-tolerant taxa, i.e. generalist, boreal, and Arcticalpine elements (Fig. 6). This correlates well with the onset of glaciation on the Iceland Plateau and off southeast Greenland (Fig. 5). The climate at this time was still significantly milder than today, as evidenced by the substantial proportion of meridio-nemoral taxa, i.e. taxa chiefly restricted to subtropical, warm temperate climates (Cfa, Cwa). The most drastic shift is seen at the transition from the Pliocene to the Pleistocene (3.6 Myr to <2.6 Myr - "IV" in Fig. 5) and corresponds to the onset of widespread Northern Hemisphere glaciations (Fronval and Jansen, 1996; St. John and Krissek, 2002). This change is expressed by a distinct drop of Cfa taxa and a marked increase of ET taxa. By this time, the modern vegetation of Iceland, dominated by boreal and Arcticalpine taxa with a few nemoral elements (Fig. 6), was established. Thus, the climatic estimates presented here largely reflect the history of IRD in the Northern Hemisphere (Fronval and Jansen, 1996; Wolf-Welling et al., 1996; Thiede et al., 1998; St. John and Krissek, 2002; Frank et al., 2008; Knies and Gaina, 2008) and of gradual cooling in the Northern Hemisphere during the late Cenozoic culminating in the Pleistocene cold phases (Zachos et al., 2001).

\section{Discussion}

Our analyses demonstrate that the palaeobotanical record of Iceland does not reflect the global climatic decline during the MMCT (Fig. 5). Global cooling was delayed in the northern North Atlantic by at least two million years. This is at odds with palaeontological records from other high-latitude regions. In East Antarctica, tundra plants and animals went extinct (Lewis et al., 2008). In northwestern North America 


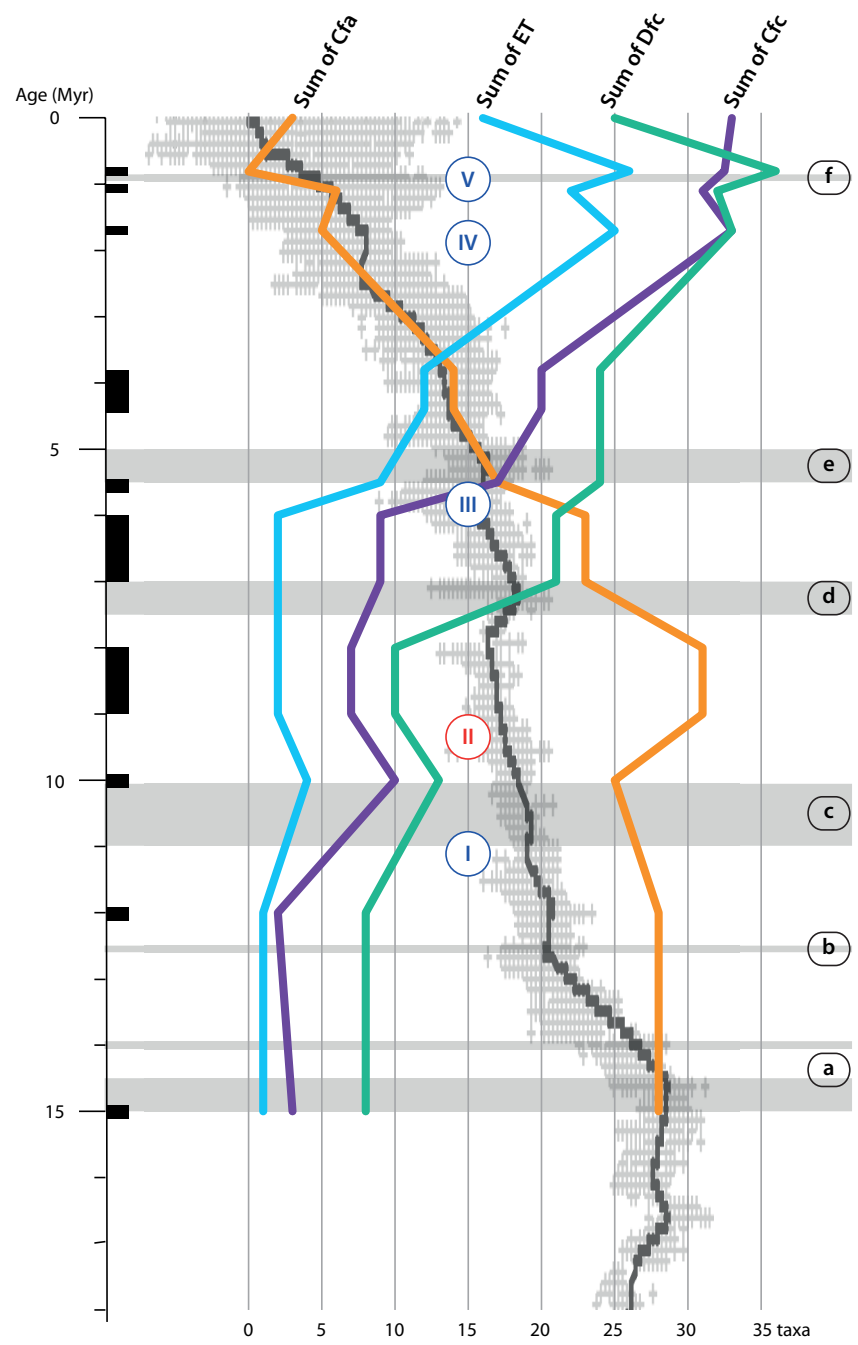

Fig. 5. Climate change over the past $15 \mathrm{Myr}$ in Iceland based on Köppen signatures of fossil taxa from Iceland (15-0.8 Myr rock units, indicated by black bars) and the modern flora of Iceland (monocots excluded) compared to global trends inferred from marine isotope $\left(\delta^{18} 0\right)$ records (grey background curve; Zachos et al., 2001). Cfa climate: warm temperate, fully humid with hot summers; Cfc: warm temperate, fully humid with cool summers; Dfc: snow climate, fully humid with cool summers; ET: polar tundra climate (Köppen, 1936; Kottek et al., 2006). Number of taxa scoring for particular climate types was scaled to 43 for all rock units. (a-f) denote phases of IRD pulses in the Northern Hemisphere: (a) glaciation in the northern Barents Sea region and Fram Strait, ODP site 909c at 15-14.5 Myr (Knies and Gaina, 2008), and at $14 \mathrm{Myr}$ in the Fram Strait, ODP sites 908, 909 (Wolf-Welling et al., 1996; Thiede et al., 1998); (b) glaciation at 12.6 Myr on the Vöring Plateau, ODP sites 642, 643, 644 (Fronval and Jansen, 1996; Thiede et al., 1998); (c) various pulses of increased IRD from Vöring Plateau and Fram Strait beginning at $\sim 11-10$ Myr (Fronval and Jansen, 1996; WolfWelling et al., 1996; Thiede et al., 1998); (d) IRD pulses at 7.5-7 Myr off SE Greenland, ODP site 918 (Larsen et al., 1994; St. John and Krissek, 2002), Iceland Plateau, ODP site 907 and Vöring Plateau, ODP sites 642, 643, 644 (Fronval and Jansen, 1996) and Fram Strait, ODP sites 908, 909 (Wolf-Welling et al., 1996; Thiede et al., 1998); (e) glaciations starting between 6 and $5 \mathrm{Myr}$ in all areas mentioned previously (Fronval and Jansen, 1996; Wolf-Welling et al., 1996; Thiede et al., 1998; St. John and Krissek, 2002); and (f) mid-Pleistocene climate transition at 0.9 Myr. (I-V) denote climate shifts inferred from floristic changes and changes in Köppen climate type distribution.

thermophilous taxa retreated (White et al., 1997). A cooling trend during the MMCT can also be observed in mid-latitude North America and Europe (reviewed in Denk et al., 2011, 251 pp.).

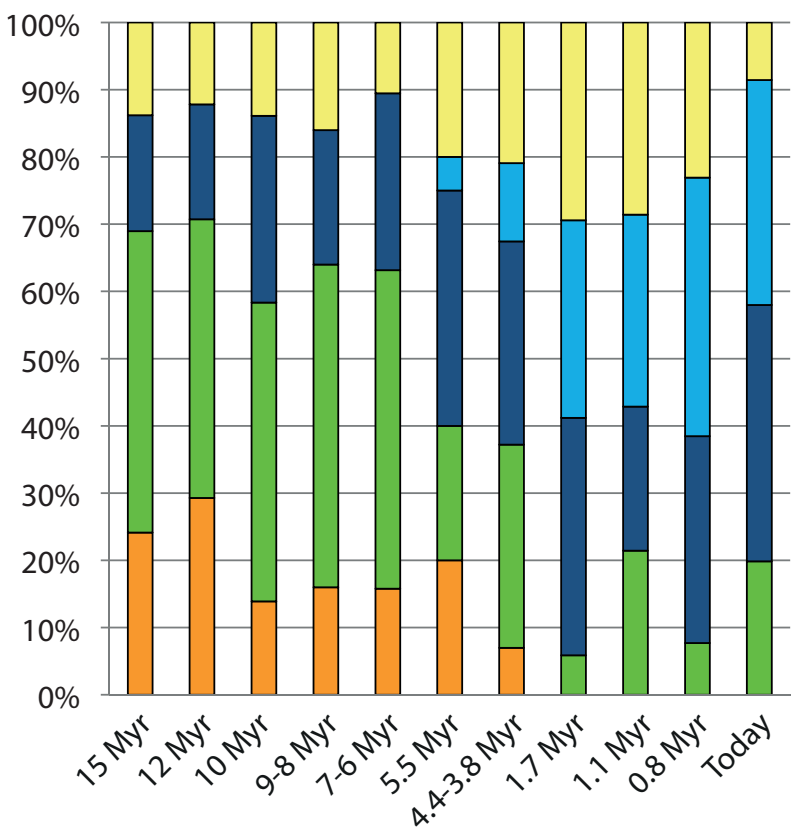

Fig. 6. Proportion of elements ascribed to major vegetation types from fossil plant assemblages and the modern flora of Iceland. Elements are categorized as meridio-nemoral (orange), nemoral (green), boreal (dark blue), Arctic-alpine (light blue), and generalists (yellow) based on their specific Köppen signatures.

\subsection{What delayed Miocene cooling in the subarctic North Atlantic?}

Northward heat transport by the Loop Current-Gulf Stream has been buffering general cooling trends in the subarctic North Atlantic since the Pliocene (Driscoll and Haug, 1998; Haug and Thiedemann, 1998; Seager et al., 2002; Kaspi and Schneider, 2011). Isotopic evidence for such an influence has previously been provided for the Pleistocene. For example, despite glacial initiation at the inception of marine isotope stage MIS 5d, $115 \mathrm{kyr}$, heat transport due to an effective Gulf Stream kept the subarctic North Atlantic warm until 107 kyr (McManus et al., 2002). The ameliorated climate in Iceland at $\sim 12 \mathrm{Myr}$ as shown by the floristic data is at odds with global climate inferences from marine isotopic records, geological data, and palaeobotanical evidence from elsewhere in the Northern and Southern Hemisphere that indicate global cooling after $15 \mathrm{Myr}$ (Wolfe, 1994; White et al., 1997; Zachos et al., 2001; Knies and Gaina, 2008; Lewis et al., 2008). The geographical position of Iceland and an already effective Loop Current-Gulf Stream explain this discrepancy. Increased thermohaline circulation and moisture transport from low to high northern latitudes by the Loop Current-Gulf Stream after $15 \mathrm{Myr}$ as a consequence of the cessation of deep marine interchange through the Central American Seaway (Mullins et al., 1987) or its closure (Montes et al., 2012) contributed to milder climates in the 
North Atlantic, in particular north of $60^{\circ} \mathrm{N}$ (Seager et al., 2002). Thus, vegetation development in Iceland provides the first direct evidence of the development and palaeoenvironmental significance (Mullins et al., 1987) of an effective Gulf Stream during the middle Miocene.

\subsection{Applicability of the proposed approach - categorization of plant taxa using Köppen climate types - to determine past climates}

Taxon-based approaches to infer past climates using plant fossil assemblages are limited by the accuracy with which fossil taxa and their modern analogues can be determined. The extent to which a PMA matches the ecological (including climatic) properties of a fossil taxon cannot be established with complete certainty. This renders actualistic approaches that use climatic tolerances of modern taxa to estimate past climates, the so-called "nearest-living-relative" approaches (Iversen, 1944; Grichuk et al., 1984; Mosbrugger and Utescher, 1997), problematic. All nearest-living-relative approaches start from the assumption of physiological uniformitarianism (Tiffney, 2008). For example, the beech trees (genus Fagus; see above) - which have a very rich fossil record and are restricted today to $\mathrm{Cfa}, \mathrm{Cfb}$, and Dfb climates - had a much wider distribution during some parts of the Cenozoic, including Arctic areas such as Ellesmere Island (Denk and Grimm, 2009a). Nevertheless, based on association evidence, beech trees formed a part of humid, warmtemperate forests typically found in modern $\mathrm{Cfa}$ and $\mathrm{Cfb}$ climates and mixed broadleaved-deciduous and conifer forests, today typically thriving under Dfb climates. Hence, scoring a Fagus fossil as Cfa, Cfb, and Dfb appears to be justified. On the other hand, it is difficult to (i) exactly determine the present climate range(s) of beeches (Grimm and Denk, 2012) and (ii) to establish whether or not fossil members of the genus occupied exactly the same climatic space.

In contrast, if evidence is available that the climatic affinity of a taxon changed during time without morphological adaptation, i.e. the assumption of physiological uniformitarianism is violated (Tiffney, 2008), the Köppen signature can be accordingly adjusted. This is not an issue for the here-used Icelandic floras, but would be the case, for example, for Miocene floras of Turkey (e.g. Denk et al., 2014). Two fossil Quercus species are abundant (Q. drymeja Unger, $Q$. mediterranea Unger), which resemble the modern Mediterranean sclerophyllous $Q$. ilex L. (Csa, rarely Cfa) and $Q$. coccifera L. (exclusively Csa) of Quercus Group Ilex, and have traditionally been associated with these modern taxa and their environments (e.g. Mai, 1995). However, phylogenetic studies of modern species of Quercus (Denk and Grimm, 2010; Simeone et al., 2013) demonstrate that most taxa of Quercus Group Ilex at present times are not Csa taxa, but typically found in Cwa and Cfa climates (into Cwb; southern foothills of the Himalayas into China; Grimm and Denk, 2012). Moreover, some of these species show leaf

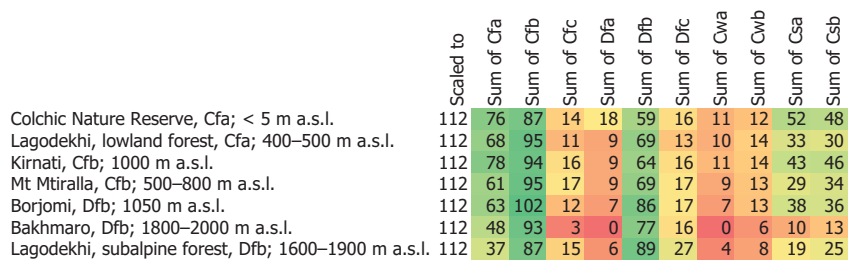

Fig. 7. Köppen climate type distribution and frequency in modern forest communities of humid temperate Georgia, Transcaucasia.

morphotypes virtually identical to both the fossil western Eurasian and the modern Mediterranean species (T. Denk and D. Velitzelos, unpublished data, 2013). The adaptation of $Q$. coccifera and $Q$. ilex to the Csa climate (probably within the last 2-3 Ma) was not accompanied by marked morphological change. Hence, Q. drymeja and Q. mediterranea would not be scored as Csa or Cfa, (Cwa, Cwb) but only as Cfa, Cwa, and Cwb based on the co-occurrence of these taxa with predominantly humid temperate taxa (e.g. Denk et al., 2014). Another example from the middle Miocene of Turkey is a recently described dragon tree species (Dracaena tayfunii; Denk et al., 2014). The fossil is virtually indistinguishable from the modern Macaronesian species D. draco (L.) L. (Csa, Csb, BS, BW climates) based on shoot architecture, leaf morphology, and epidermal features. The associated plant assemblage as well as the depositional environment exclude arid or summer dry climates. Instead, a monsoon-influenced or fully humid subtropical climate is indicated (Cfa, Cwa; Denk et al., 2014; see also Güner and Denk, 2012). Hence, one would score Miocene fossil dragon trees with affinity to the $D$. draco lineage as Cfa, Cwa and not as Csa, Csb, BS, and BW.

A further complication is that the distribution of a taxon is affected by several partly antagonistic biotic and abiotic parameters (see above). Köppen (1936, p. 11) had already noticed that absolute climatic figures, in particular if taken independently (Wolfe, 1993; Wolfe, 1995; Mosbrugger and Utescher, 1997), are not meaningful indicators of vegetation types and general climate types. This is well illustrated by Schroeder (1998), who used Walter climate diagrams (Walter and Lieth, 1960, 1964) to document the variation of climatic conditions for particular vegetation types (see also Tables 3 and 4). In other words, any plant assemblage can only reflect a range of climatic conditions but not the exact parameters of a particular climate as for example available for climate stations.

\section{Outlook}

A future application of the approach proposed here may be to infer a particular Köppen climate for a plant fossil assemblage. However, several issues must be addressed first. Rich plant fossil assemblages like the ones used here often 


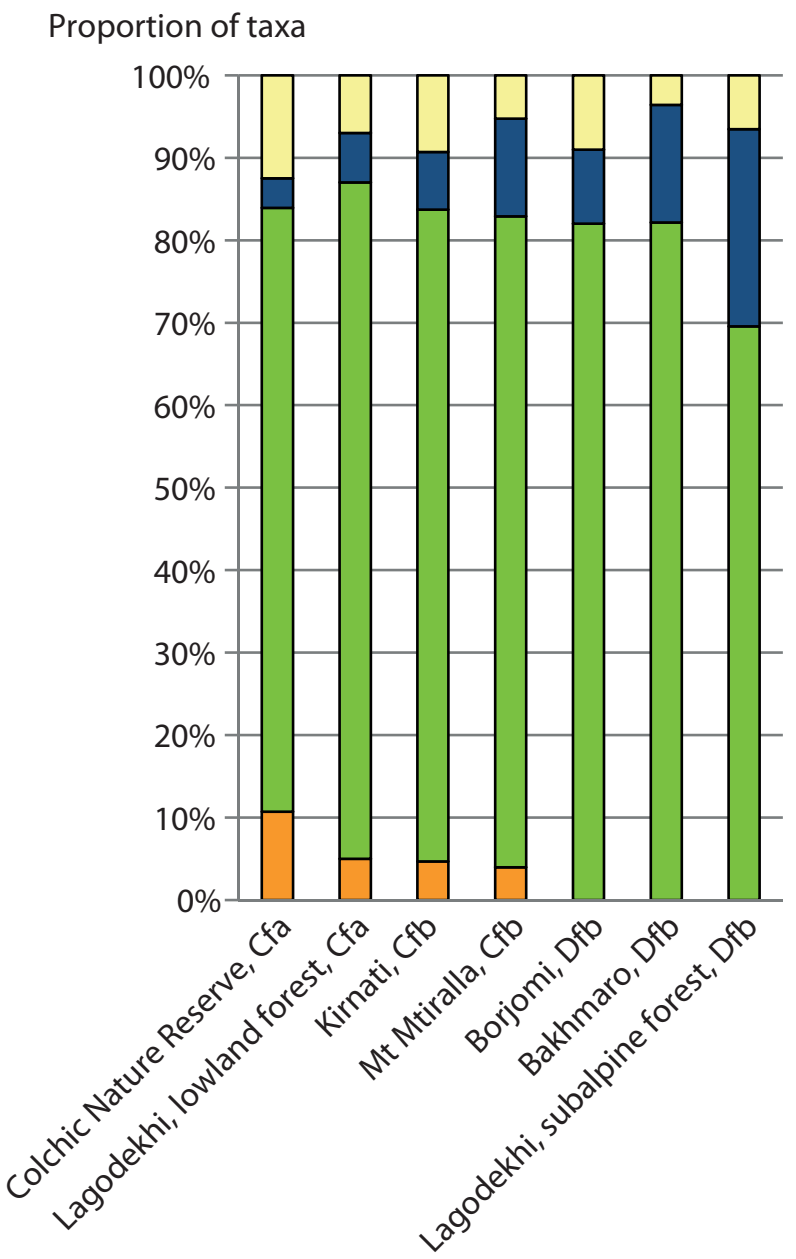

Fig. 8. Proportion of elements ascribed to major vegetation types in modern forest communities of humid temperate Georgia, Transcaucasia. Elements are categorized as meridio-nemoral (orange), nemoral (green), boreal (dark blue), and generalists (yellow) based on their specific Köppen signatures.

combine taxa from a larger area, and hence involve a certain altitudinal gradient. The first step, therefore, would be to divide the fossil taxa into lowland and highland groups (Denk et al., 2011). A further step would be to characterize Köppen climates by Köppen signatures of taxa thriving in these climates and the corresponding vegetation categories. Figure 7 shows the Köppen climate type frequencies for several broadleaved deciduous and conifer forests of Georgia, Transcaucasia (Denk et al., 2001), thriving under Cfa to Dfb climates. The $\mathrm{Cfa}$ and $\mathrm{Cfb}$ forests show essentially the same patterns and are predominantly composed of taxa that thrive in $\mathrm{Cfb}$ climates. More than half of the taxa can (also) occur in Cfa and/or Dfb climates, whereas one-third to onehalf can (also) thrive in Csa/Csb climates. In the Dfb forests the numbers of taxa occurring in Dfb climates increase and $\mathrm{Cfa}(\mathrm{Csa} / \mathrm{Csb})$ taxa decrease. Using vegetation categories (Fig. 8), the different climates are better resolved. From Cfa to Dfb the proportion of meridio-nemoral elements decreases and that of boreal elements increases. The general high proportion of nemoral elements (Fig. 8) and number of taxa scoring for Cfa (Fig. 7) can be attributed to the particular phytogeographical position of Georgian forests, which have been providing a refuge for numerous warmth-loving taxa that went extinct in Europe during the Pleistocene (e.g. Diospyros L., Hibiscus L., Osmanthus Lour., Pterocarya, Zelkova Spach; Denk et al., 2001). The comparison of adequate modern reference floras to fossil ones then may enable one to infer specific Köppen climate types for the lowland and highland portions of a fossil assemblage.

\section{Supplementary material related to this article is available online at http://www.biogeosciences.net/10/ 7927/2013/bg-10-7927-2013-supplement.zip.}

Acknowledgements. T. Denk and G. W. Grimm acknowledge funding by the Swedish Research Council (VR), grants 2009-4354 and 2008-3726; F. Grímsson by the Austrian Science Fund (FWF), grant M1181-B17. Comments by Stephen McLoughlin improved the manuscript.

Edited by: W. Kiessling

\section{References}

Anderberg, A. and Anderberg, A.-L. Den virtuella floran, Naturhistoriska riksmuseet, last accessed 14/12/2012, 2010.

Barry, R. G. and Chorley, R. J.: Atmosphere, Weather, and Climate, Routledge, London, 472 pp., 2003.

Browicz, K.: Chorology of Trees and Shrubs in South-West Asia and Adjacent Regions, Vol. 5, Polish Scientific Publishers, Warsaw, Poznan, 88 pp., 1986.

Browicz, K. and Zieliński, J.: Chorology of Trees and Shrubs in South-West Asia and Adjacent Regions, Vol. 1, Polish Scientific Publishers, Warsaw, Poznan, 172 pp., 1982.

Browicz, K. and Zieliński, J.: Chorology of Trees and Shrubs in South-West Asia and Adjacent Regions. 10 vols, Polish Scientific Publishers, Poznan, 172; 183; 185; 179; 187; 186; 185; 185; 183; 100 pp., 1982-1994.

Browicz, K. and Zieliński, J.: Chorology of Trees and Shrubs in South-West Asia and Adjacent Regions, Vol. 2, Polish Scientific Publishers, Warsaw, Poznan, 79 pp., 1984.

Cao, K.-F.: Fagus dominance in Chinese montane forests, $\mathrm{Ph} . \mathrm{D}$. thesis, Landbouw- en milieuwetenschappen Landbouwuniversiteit te Wageningen, Wageningen, 115 pp., 1995.

Denk, T. and Grimm, G. W.: The biogeographic history of beech trees, Rev. Palaeobot. Palynol., 158, 83-100, 2009a.

Denk, T. and Grimm, G. W.: Significance of pollen characteristics for infrageneric classification and phylogeny in Quercus (Fagaceae), Int. J. Plant Sci., 170, 926-940, 2009 b.

Denk, T. and Grimm, G. W.: The oaks of western Eurasia: traditional classifications and evidence from two nuclear markers, Taxon, 59, 351-366, 2010. 
Denk, T., Frotzler, N., and Davitashvili, N.: Vegetational patterns and distribution of relict taxa in humid temperate forests and wetlands of Georgia (Transcaucasia), Biol. J. Linn. Soc., 72, 287332, 2001.

Denk, T., Grimm, G. W., and Hemleben, V.: Patterns of molecular and morphological differentiation in Fagus: implications for phylogeny., Am. J. Bot., 92, 1006-1016, 2005a.

Denk, T., Grímsson, F., and Kvaček, Z.: The Miocene floras of Iceland and their significance for late Cainozoic North Atlantic biogeography, Bot. J. Linn. Soc., 149, 369-417, 2005 b.

Denk, T., Grímsson, F., and Zetter, R.: Episodic migration of oaks to Iceland - evidence for a North Atlantic "land bridge" in the latest Miocene, Am. J. Bot., 97, 276-287, 2010.

Denk, T., Grímsson, F., Zetter, R., and Símonarson, L. A.: Late Cainozoic Floras of Iceland: 15 Million Years of Vegetation and Climate History in the Northern North Atlantic., Topics in Geobiology, Springer, Heidelberg, New York, 854 pp., 2011.

Denk T., Güner H. T., and Grimm, G. W. From mesic to arid: Leaf epidermal features suggest preadaptation in Miocene dragon trees (Dracaena), Rev. Palaeobot. Palynol., 200, 211-228, 2014.

Driscoll, N. W. and Haug, G. H.: A short circuit in thermohaline circulation: A cause for Northern Hemisphere glaciation?, Science, 282, 436-438, 1998.

Duque-Caro, H.: Neogene stratigraphy, paleoceanography and paleobiogeography in northwest South America and the evolution of the Panama Seaway, Palaeogeogr. Palaeocl., 77, 203-234, 1990.

Fang, J., Wang, Z., and Tang, Z.: Atlas of Woody Plants in China. Volumes 1 to 3 and index, Higher Education Press, Beijing, 2009.

Farjon, A.: Pinaceae, Koeltz Scientific Books, Königstein, 330 pp., 1990.

Flora of China: Flora of China @ efloras.org, Missouri Botanical Garden, St. Louis, MO \& Harvard University Herbaria, Cambridge, MA, last accessed 10/02/2013, 2013.

Flower, B. P. and Kennett, J. P.: Middle Miocene deepwater paleoceanography in the southwest Pacific: relations with East Antarctic Ice Sheet development, Paleoceanography, 10, 1095-1112, 1995.

Frank, M., Backman, J., Jakobsson, M., Moran, K., O'Regan, M., King, J., Haley, B. A., Kubik, P. W., and GarbeSchönberg, D.: Beryllium isotopes in central Arctic Ocean sediments over the past 12.3 million years: Stratigraphic and paleoclimatic implications, Paleoceanography, 23, PA1S02, doi:10.1029/2007PA001478, 2008.

Friedrich, W. L. and Símonarson, L. A.: Acer-Funde aus dem Neogen von Island und ihre stratigraphische Stellung, Palaeontographica B, 182, 151-166, 1982.

Fronval, T. and Jansen, E.: Late Neogene paleoclimates and paleoceanography in the Iceland-Norwegian Sea: evidence from the Iceland and Vøring plateaus, Proceedings of the Ocean Drilling Program, Scientific Results, 151, 455-468, 1996.

Grichuk, V. P., Gurtovaya, Y. Y., Zelikson, E. M., and Borisova, O. K.: Methods and results of late Pleistocene paleoclimatic reconstructions., in: Late Quarternary environments of the Soviet Union, edited by: Velichko, A. A., Longman, London, 251-260, 1984.

Grimm, G. W. and Denk, T.: Reliability and resolution of the coexistence approach - A revalidation using modern-day data, Rev. Palaeobot. Palynol., 172, 33-47, 2012.
Grimm, G. W., Denk, T., and Hemleben, V.: Evolutionary history and systematic of Acer section Acer - a case study of low-level phylogenetics, Plant Syst. Evol., 267, 215-253, 2007.

Güner T. H. and Denk, T. The genus Mahonia in the Miocene of Turkey: Taxonomy and biogeographic implications, Rev. Palaeobot. Palynol., 175, 32-46, 2013.

Hardarson, B. S., Fitton, J. G., Ellam, R. M., and Pringle, M. S.: Rift relocation - a geochemical and geochronological investigation of a palaeo-rift in northwest Iceland, Earth Planet. Sci. Lett., 153, 181-196, 1997.

Haug, G. H. and Thiedemann, R.: Effect of the formation of the Isthmus of Panama on Atlantic Ocean thermohaline circulation, Nature, 398, 673-676, 1998.

Hegi, G.: Illustrierte Flora von Mitteleuropa. Band IV, Teil 2b. Rosaceae, 2. Teil., 1st ed., Lehmann, München, 615 pp., 1923.

Hegi, G.: Illustrierte Flora von Mitteleuropa. Band VI, Teil 1. Dicotyledones, 5. Teil (Scrophulariaceae-Asteraceae), 1st ed., J. F. Lehmanns, München, 544 pp., 1928.

Hegi, G.: Illustrierte Flora von Mitteleuropa. Band V, Teil 1. Linaceae-Violaceae., 2nd ed., Paul Parey, Berlin, Hamburg, 688 pp., 1966a.

Hegi, G.: Illustrierte Flora von Mitteleuropa. Band IV, Teil 2a. Droseraceae-Rosaceae, 1. Teil., 2nd ed., Paul Parey, Berlin, Hamburg, 448 pp., 1966b.

Hegi, G.: Illustrierte Flora von Mitteleuropa. Band III, Teil 3. Nymphaeaceae-Ranunculaceae, 2nd ed., Paul Parey, Berlin, Hamburg, 364 pp., 1974.

Hegi, G.: Illustrierte Flora von Mitteleuropa. Band III, Teil 1. Juglandaceae-Polygonaceae., 3rd ed., Paul Parey, Berlin, Hamburg, 504 pp., $1981 \mathrm{a}$.

Hegi, G.: Illustrierte Flora von Mitteleuropa. Band I, Teil 2. Ginkgoaceae-Scheuchzeriaceae., 3rd ed., Paul Parey, Berlin, Hamburg, 270 pp., 1981 b.

Hegi, G.: Illustrierte Flora von Mitteleuropa. Band I, Teil 1. Pteridophyta., 3rd ed., Paul Parey, Berlin, Hamburg, 309 pp., 1984.

Iversen, J.: Viscum, Hedera, and Ilex as climate indicators. A contribution to the study of the post-glacial temperature climate, Geol. Fören. Stock. För., 66, 463-483, 1944.

Jakobsson, M., Backman, J., Rudels, B., Nycander, J., Frank, M., Mayer, L., Jokat, W., Sangiorgi, F., O’Regan, M., Brinkhuis, H., King, J., and Moran, K.: The Early Miocene Onset of a Ventilated Circulation Regime in the Arctic Ocean, Nature, 447, 986-990, 2007.

Kaspi, Y. and Schneider, T.: Winter cold of eastern continental boundaries induced by warm ocean waters, Nature, 471, 621625, 2011.

Keller, G. and Barron, J. A.: Paleoceanographic implications of the Miocene deep-sea hiatuses, Geol. Soc. Am. Bull., 94, 590-613, 1983.

Knies, J. and Gaina, C.: Middle Miocene ice sheet expansion in the Arctic: Views from the Barents Sea, Geochem. Geophy. Geosy., 9, Q02015, doi:10.1029/2007GC001824, 2008.

Kottek, M., Grieser, J., Beck, C., Rudolf, B., and Rubel, F.: World map of the Köppen-Geiger climate classification updated, Meteorol. Z., 15, 259-263, 2006.

Kristjansson, L., Hardarson, P. S., and Audunsson, H.: A detailed palaeomagnetic study of the oldest $(\approx 15 \mathrm{Myr})$ lava sequences in Northwest Iceland, Geophys. J. Int., 155, 991-1005, 2003. 
Köppen, W.: Die Wärmezonen der Erde, nach der Dauer der heissen, gemässigten und kalten Zeit und nach der Wirkung der Wärme auf die organische Welt betrachtet, Meteorol. Z., 1, 215226,1884

Köppen, W.: Das geographische System der Klimate, in: Handbuch der Klimatologie, Band 1, Teil C., edited by: Köppen, W. and Geiger, R., Gebr. Borntraeger, Berlin, 1-44, 1936.

Köppen, W. P. and Wegener, A.: Die Klimate der geologischen Vorzeit, Gebrüder Borntraeger, Berlin, Stuttgart, 255 pp., 1924.

Larsen, H. C., Saunders, A. D., Clift, P. D., Beget, J., Wei, W., and Spezzaferri, S.: Seven million years of glaciation in Greenland, Science, 264, 952-955, 1994.

Lewis, A. R., Marchant, D. R., Ashworth, A. C., Hedenäs, L., Hemming, S. R., Johnson, J. V., Leng, M. J., Machlus, M. L., Newton, A. E., Raine, J. I., Willenbring, J. K., Williams, M., and Wolfe, A. P.: Mid-Miocene cooling and the extinction of tundra in continental Antarctica, P. Natl. Acad. Sci. USA, 105, 10676-10680, 2008

Lieth, H., Berlekamp, J., Fuest, S., and Riediger, S.: Climate Diagram World Atlas on CD, Backhuys Publ. B. V., Leiden, 1999.

Mai, D. H.: Tertiäre Vegetationsgeschichte Europas, Gustav Fischer Verlag, Stuttgart, 691 pp., 1995.

Maycock, P. F.: The ecology of beech (Fagus grandifolia Ehrh.) forests of the deciduous forests of southeastern North America, and a comparison with the beech (Fagus crenata) forests of Japan, in: Vegetation in Eastern North America, edited by: Miyawaki, A., Iwatsuki, K., and Grandtner, M. M., University of Tokyo Press, Tokyo, 515, 1994.

McDougall, I., Kristjansson, L., and Saemundsson, K.: Magnetostratigraphy and Geochronology of Northwest Iceland, J. Geophys. Res., 89, 7029-7060, 1984.

McManus, F. J., Oppo, D. W., Keigwin, L. D., Cullen, J. L., and Bond, G. C.: Thermohaline circulation and prolonged interglacial warmth in the North Atlantic, Quatern. Res., 58, 17-21, 2002.

Montes, C., Bayona, G., Cardona, A., Buchs, D. M., Silva, C. A., Morón, S., Hoyos, N., Ramírez, D. A., Jaramillo, C. A., and Valencia, V.: Arc-continent collision and orocline formation: closing of the Central American seaway, J. Geophys. Res., 117, B04105, 2012.

Mosbrugger, V. and Utescher, T.: The coexistence approach - a method for quantitative reconstructions of Tertiary terrestrial palaeoclimate data using plant fossils, Palaeogeogr., Palaeocl., 134, 61-86, 1997.

Mullins, H. T., Gardulski, A. F., Wise, S. W., and Applegate, J.: Middle Miocene oceanographic event in the eastern Gulf of Mexico: implications for seismic stratigraphic succession and Loop Current/Gulf Stream circulation, Geol. Soc. Am. Bull., 98, 702$713,1987$.

Nisancioglu, K. H., Raymo, M. E., and Stone, P. H.: Reorganization of Miocene deep water circulation in response to the shoaling of the Central American Seaway, Paleoceanography, 18, 1006, doi:10.1029/2002PA000767, 2003.

Ohwi, J.: Flora of Japan, Smithsonian Institution, Washington, DC, 1067 pp., 1965.

Peel, M. C., Finlayson, B. L., and McMahon, T. A.: Updated world map of the Köppen-Geiger climate classification, Hydrol. Earth Syst. Sci., 11, 1633-1644, doi:10.5194/hess-11-16332007, 2007.
Peters, R.: Beech forests, Geobotany, 24, 1-169, 1997.

Rubel, F. and Kottek, M.: Observed and projected climate shifts 1901-2100 depicted by world maps of the Köppen-Geiger climate classification, Meteorol. Z., 19, 135-141, 2010.

Schroeder, G.-F.: Lehrbuch der Pflanzengeographie, Quelle \& Meyer, Wiesbaden, 459 pp., 1998.

Seager, R., Battisti, D. S., Yin, J., Gordon, N., Naik, N., Clement, A. C., and Cane, M. A.: Is the Gulf Stream responsible for Europe's mild winters?, Q. J. Roy. Meteor. Soc., 128, 2536-2586, 2002.

Shen, C. F.: A monograph of the genus Fagus Thurn. ex L. (Fagaceae). Ph.D. thesis, City University of New York, New York, 1992.

Shevenell, A. E., Kennett, J. P., and Lea, D. W.: Middle Miocene Southern Ocean cooling and Antarctic cryosphere expansion, Science, 305, 1766-1770, 2004.

Simeone, M. C., Piredda, R., Papini, A., Vessella, F., and Schirone, B.: Application of plastid and nuclear markers to DNA barcoding of Euro-Mediterranean oaks (Quercus, Fagaceae): problems, prospects and phylogenetic implications, Bot. J. Linn. Soc., 172, 478-499, 2013.

St. John, K. E. K. and Krissek, L. A.: The late Miocene to Pleistocene ice-rafting history of southeast Greenland, Boreas, 31, 28-35, 2002

Thiede, J., Winkler, A., Wolfwelling, T., Eldholm, O., Myhre, A. M., Baumann, K. H., Henrich, R., and Stein, R.: Late Cenozoic history of the polar North Atlantic - results from ocean drilling, Quaternary Sci. Rev. 17, 185-208, 1998.

Thompson, R. S., Anderson, K. H., and Bartlein, P. J.: Atlas of relations between climatic parameters and distributions of important trees and shrubs in North America - Introduction and Conifers, U.S. Geological Survey Professional Paper, 1650-A, $1-269,1999$ a.

Thompson, R. S., Anderson, K. H., and Bartlein, P. J.: Atlas of relations between climatic parameters and distribution of important trees and shrubs in North America - Hardwoods, US Geological Survey Professional Paper, 1650-B, 1-423, 1999b.

Thompson, R. S., Anderson, K. H., and Bartlein, P. J.: Atlas of relations between climatic parameters and distributions of important trees and shrubs in North America - Additional conifers, hardwoods, and monocots, U.S. Geological Survey Professional Paper, 1650-C, 1-386, 2001.

Thompson, R. S., Anderson, K. H., Strickland, L. E., Shafer, S. L., Pelltier, R. T., and Bartlein, P. J.: Atlas of Relations Between Climatic Parameters and Distributions of Important Trees and Shrubs in North America-Alaska Species and Ecoregions, U.S. Geological Survey Professional Paper, 1650-D, 1-342, 2006.

Tiffney, B. H.: Phylogeography, fossils, and Northern Hemisphere biogeography: the role of physiological uniformitarianism, Ann. Mo. Bot. Garden, 95, 135-143, 2008.

Walter, H.: Vegetation of the Earth in relation to the climate and the eco-physiological conditions, Springer Verlag, New York, Heidelberg, Berlin, 237 pp., 1973.

Walter, H. and Lieth, H.: Klimadiagramm-Weltatlas, 1. Lieferung, VEB Gustav Fischer Verlag, Jena, s.n. pp., 1960

Walter, H. and Lieth, H.: Klimadiagramme-Weltatlas. 2. Lieferung, VEB Gustav Fischer Verlag, Jena, s.n. pp., 1964.

Walther, H.: Studien über tertiäre Acer Mitteleuropas, Abhandlungen des Staatlichen Museums für Mineralogie und Geologie zu Dresden, 19, 1-309, 1972. 
Wang, C.-W.: The Forests of China with a Survey of Grassland and Desert Vegetation, Maria Moors Cabot Foundation Publication, Harvard University, Cambridge, MA, 1961.

Wegener, A.: Die Entstehung der Kontinente und Ozeane, 4th ed., Friedr. Vieweg \& Sohn Akt.-Ges., Braunschweig, 231 pp., 1929.

White, J. M., Ager, T. A., Adam, D. P., Leopold, E. B., Liu, G., Jetté, H., and Schweger, C. E.: An 18 million year record of vegetation and climate change in northwestern Canada and Alaska: tectonic and global correlates, Palaeogeogr. Palaeocl., 130, 293306, 1997.

Wolf-Welling, T. C. W., Cremer, M., O’Connell, S., Winkler, A., and Thiede, J.: Cenozoic Arctic Gateway paleoclimate variability: indications from changes in coarse-fraction composition, Proceedings of the Ocean Drilling Program, Scientific Results, 151, 515-567, 1996.
Wolfe, J. A.: A method of obtaining climatic parameters from leaf assemblages, U.S. Geol. Survey Bull., 2040, 1-73, 1993.

Wolfe, J. A.: An analysis of Neogene climates in Beringia, Palaeogeogr., Palaeocl., 108, 207-216, 1994.

Wolfe, J. A.: Paleoclimatic estimates from Tertiary leaf assemblages, Ann. Rev. Earth Planet. Sci., 23, 119-142, 1995.

Zachos, J. C., Pagani, M., Sloan, L., Thomas, E., and Billups, K.: Trends, rhythms, and aberrations in global climate $65 \mathrm{Ma}$ to present, Science, 292, 686-693, 2001. 